of pathogenic antibodies to the thyroid stimulating hormone receptor.

The Netherlands Organisation for Medical and Health Research (MEDIGON) and the Advancement of Pure Research (ZWO) provided financial support for this study. Drs J D'Amaro and P de Lange performed part of the Woolfe-Haldane analysis. We thank Rineke de Graaf and Carina van den Haak for typing the manuscript.

\section{References}

1 Adams DD. Thyroid-stimulating autoantibodies. Vitam Horm 1980;38:119-203.

2 Burman KD, Baker JR Jr. Immune mechanisms in Graves' disease. Endocr Rev 1985;6:183-232.

3 DeGroot LJ, Stanbury JB. The thyroid and its diseases. 4th ed. New York: John Wiley and Sons, 1975:249-367.

4 McKenzie JM, Zakarija M. Hyperthyroidism. In: DeGroot L, Cahill GF, Odell WO, et al, eds. Endocrinology. Vol 1. New York: Grune and Stratton, 1980:429-59.

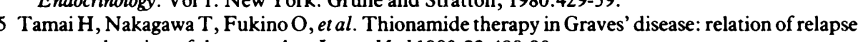
rate to duration of therapy. Ann Intern Med 1980;92:488-90.

6 Farid NR, Bear JC. The human major histocompatibility complex and endocrine disease. Endocr Rev 1981;2:50-86.

7 McGregor AM, Smith BR, Hall R, Petersen MM, Miller M, Dewar PJ. Prediction of relapse in hyperthyroid Graves' disease. Lancet 1980;i:1101-3.

8 Teng CS, Yeung RTT. Changes in thyroid-stimulating antibody activity in Graves' disease treated with antithyroid drugs and its relationship to relapse: a prospective study. $\mathcal{J}$ Clin Endocrinol Metab 1980;50:144-7.

9 Allanic H, Fauchet R, Lorcy Y, Guenquen M, Le Guerrier A-M, Genetet B. A prospective study of the relationship between relapse of hyperthyroid Graves' disease after antithyroid drugs and HLA haplotype. J Clin Endocrinol Metab 1983;57:719-22.

10 Wilson R, McKillop JH, Henderson N, Pearson DW, Thomson JA. The ability of the serum thyrotrophin receptor antibody (TRAb) index and HLA-status to predict long-term remission of thyrotoxicosis following medical therapy for Graves' disease. Clin Endocrinol (Oxf) 1986;25: $151-6$.

11 Weetman AP, Ratanachaiyavong S, Middleton GW, et al. Prediction of outcome in Graves' disease after carbimazole treatment. Qf Med 1986;59:409-19.

12 Werner SC. Modification of the classification of the eye changes of Graves' disease: recommendations of the ad hoc committee of the American Thyroid Association. 7 Clin Endocrinol Metab 1977;44:203-4.
13 Van der Heide D, Daha MR, Bolk JH, et al. Circulating immune complexes and thyroidstimulating immunoglobulins before, during, and after antithyroid drug therapy in patients with Graves' disease. Lancet 1980; 1 :1376-80.

14 Mittal KD, Mickey MR, Singal DP, Terasaki PI. Serotyping for homotransplantation. XVIII. Refinement of microdroplet lymphocyte toxicity test. Transplantation 1968;6:913-27.

15 Van Rood JJ, van Leeuwen A, Ploem JS. Simultaneous detection of two cell populations by two-colour fluorescence and application to the recognition of B-cell determinants. Nature two-colour fluor $1976 ; 262: 795-7$.

16 Woolf B. On estimating the relation between blood group and disease. Ann Hum Genet 1955;19:251-3.

17 Haldane JBS. The estimation and significance of the logarithm of a ratio of frequencies. Ann Hum Genet 1955;20:309-11.

18 Svejgaard A, Platz B, Ryder LP. HLA and disease susceptibility: clinical implications. Cinics in Immunology and Allergy. 1984;4:567-80.

19 Reinwein D, Benker G, König M-P, et al. Hyperthyroidism in Europe: clinical and laboratory data of a prospective multicentre study. F Endocrinol Invest 1986;9(suppl 2):1-35.

20 Davies TF, Yeo PPB, Evered DC, Clark F, Smith BR, Hall R. Value of thyroid-stimulating antibody determinations in predicting short-term thyrotoxic relapse in Graves' disease. Lancet 1977;ii:1181-2.

21 O’Donnell J, Trokoudes K, Silverberg J, Row VV, Volpé R. Thyrotropin displacement activity of serum immunoglobulins from patients with Graves' disease. $\mathcal{f}$ Clin Endocrinol Metab 1978;46:770-7.

22 Laurberg P, Hausen PEB, Iversen E, Jensen SE, Weeke J. Goitre size and outcome of medical reatment of Graves' disease. Acta Endocrinol (Copenh) 1986;111:39-43.

23 Jansson R, Säfwenberg J, Dahlberg PA. Influence of the HLA-DR4 antigen and iodine status on the development of autoimmune postpartum thyroiditis. F Clin Endocrinol Metab 1985;60: 168-73.

24 Bech K, Lumholtz B, Nerup J, et al. HLA antigens in Graves' disease. Acta Endocrinol (Copenh) 1977;86:510-6.

25 Dahlberg PA, Holmlund G, Karlsson EA, Safwenberg J. HLA-A;B;C; and DR antigens in patients with Graves' disease and their correlation with signs and clinical course. Acta Endocrinol (Copenh) 1981;97:42-7.

26 Allanic H, Fauchet R, Lorcy Y, et al. HLA and Graves' disease: an association with HLA-DRw3. $f$ Clin Endocrinol Metab 1980;51:863-7.

27 Hanafusa T, Pujol-Borrell R, Chiovato L, Russell RCG, Doniach D, Botazzo GF. Aberrant expression of HLA-DR antigen on thyrocytes in Graves' disease: relevance for autoimmunity. Lancet 1983;ii:1111-5.

28 Tötterman TH, Karlsson FA, Bengtsson M, Mendel-Hartvig I. Introduction of circulating activated suppressor-like T cells by methimazole therapy for Graves' disease. $N$ Engl f Med 1987;316:15-22.

29 Adams DD. Protection from autoimmune disease as the third function of the major histocompatibility gene complex. Lancet 1987;ii:245-9.

(Accepted 23 December 1987)

\title{
Prevalence, concentration, and prognostic importance of proteinuria in patients with malignancies
}

\author{
NICK SAWYER, JANE WADSWORTH, MARC WIJNEN, ROGER GABRIEL
}

\begin{abstract}
Protein was found significantly more frequently in single urine samples from 504 patients with malignancy $(290 ; 58 \%)$ than in 529 controls $(119 ; 22 \%)(p<0.001)$. Median protein concentration was greater $(p<0.001)$ in patients with neoplasia $(0.14 \mathrm{~g} / 1)$ than in controls $(0.07 \mathrm{~g} / \mathrm{l})$. Actuarial analysis showed a median survival of 4.5 months in patients with proteinuria compared with 10 months in those without $(p<0.001)$. The association between proteinuria and shorter survival was statistically significant for patients with gut tumours, lung tumours, and tumours at other sites analysed
\end{abstract}

Renal Unit, St Mary's Hospital, London W2 1NY

NICK SAWYER, MB, MRCP, research registrar

MARC WIJNEN, medical student

ROGER GABRIEL, MSC, FRCP, renal physician Department of Community Medicine, St Mary's Hospital Medical School,
London

JANE WADSWORTH, BSC, MSC, lecturer in statistics

Correspondence to: Dr Gabriel. as a group. Patients with myeloma or urinary tract tumours were not studied.

In many patients with malignancy the presence of proteinuria may be associated with a substantially reduced survival time.

\section{Introduction}

Proteinuria, often heavy, is an infrequent but well recognised complication of many different malignancies. ${ }^{12}$ Histologically membranous nephropathy is most often present, ${ }^{34}$ but minimal change is typically found in patients with lymphomas. ${ }^{56}$ Tumour products were detected in glomeruli in a patient with colonic carcinoma ${ }^{7}$ and tumour antigen was eluted from the kidneys of a patient with the nephrotic syndrome and malignant melanoma. ${ }^{8}$ Renal tissue obtained at necropsy from patients who had reticuloendothelial tumours contained C3, immunoglobulins, and electron dense deposits in glomeruli, ${ }^{910}$ suggesting subclinical deposition of immune complexes. These observations were confirmed in patients who had died of gut tumours. ${ }^{11}$

Low concentrations of proteinuria may be found in patients with advanced neoplastic disease ${ }^{12}$ and extrarenal carcinomas. ${ }^{13}$ The Framingham study showed that proteinuria was associated with increased mortality after controlling for cardiovascular risk factors. ${ }^{14}$ The data are being examined to see whether proteinuria 
was associated with neoplasia (W B Kannel, personal communication, 1985).

In diabetic patients microalbuminuria is predictive of complications. ${ }^{15}$ Proteinuria has also been documented as a consequence of trauma and burns, when it is proportional to the severity of injury. ${ }^{16}$ We report the results of a prospective study to determine the prevalence and concentration of proteinuria in patients with tumours. Survival of patients with and without proteinuria was compared.

\section{Patients and methods}

Nursing staff were asked to obtain clean catch urine samples from patients with malignancy and from patients in the same wards considered not to have tumours. This second group served as controls but matching for age and sex was not attempted. Samples were collected from July 1981 to December were considered to have survived 0.5 months. Those whose names were not found in the OPCS records (143 patients) were considered to be alive six months after the last outpatient visit.

Chemical analysis-Urine was assayed by standard automated methods for the concentrations of total protein, creatinine, urea, sodium, and potassium. Protein was precipitated by sulphosalicylic acid and measured turbinometrically. The samples formed part of the routine laboratory workload; assay techniques remained unchanged throughout. In our laboratory the coefficient of variation of the protein assay was $5 \%$ at a concentration of $0.65 \mathrm{~g} / \mathrm{l}$ ( $\mathrm{J}$ Glenn, personal communication, 1985). Electrophoresis was performed on 15 samples to characterise the proteinuria.

Statistical analysis-Non-parametric analysis was performed; median values are presented together with range or interquartile range (encompassing $50 \%$ of results) as the data were not normally distributed ${ }^{17}$ Controls and patients with malignancy were analysed according to the presence or absence of proteinuria and in two other groups according to a urinary protein concentration of up to $0 \cdot 1 \mathrm{~g} / 1$ and $0 \cdot 1 \mathrm{~g} / 1$ and more. Wilcoxon's rank sum

TABLE I-Characteristics of patients stratified by presence or absence of proteinuria. Except where stated otherwise figures are median values (interquartile ranges)

\begin{tabular}{|c|c|c|c|c|}
\hline & \multicolumn{2}{|c|}{$\begin{array}{l}\text { Proteinuria in controls } \\
\qquad(\mathrm{n}=529)\end{array}$} & \multicolumn{2}{|c|}{$\begin{array}{l}\text { Proteinuria in patients with neoplasia } \\
\qquad(\mathrm{n}=504)\end{array}$} \\
\hline & Absent & Present & Absent & Present \\
\hline $\begin{array}{l}\text { No }(\%) \text { of patients } \\
\text { Sex ratio }(\mathbf{M} / \mathbf{F}) \\
\text { Age }(\text { years }) \\
\text { Urinary creatinine }(\mathrm{mmol} / \mathrm{l}) \\
\text { Urinary urea }(\mathrm{mmol} / \mathrm{l}) \\
\text { Urinary sodium }(\mathrm{mmol} / \mathrm{l}) \\
\text { Urinary potassium }(\mathrm{mmol} / \mathrm{l})\end{array}$ & $\begin{array}{l}410(78) \\
67 / 33 \\
53(40-64) \\
8 \cdot 0(4 \cdot 5-12 \cdot 5) \\
213(128-303) \\
85(56-123) \\
39(24-63)\end{array}$ & $\begin{array}{l}119(22) \\
51 / 49 \\
57(39-69) \\
9 \cdot 0(5 \cdot 5-12 \cdot 7) \\
231(170-298) \\
74(42-106) \\
43(28-62)\end{array}$ & $\begin{array}{l}214(42) \\
49 / 51^{\star \star} \\
63(54-73) \\
6 \cdot 9(3 \cdot 9-11 \cdot 5)^{\star \star} \\
191(116-300)^{\star \star} \\
75(40-106)^{\star} \\
39(24-57)\end{array}$ & $\begin{array}{l}290(58) \\
65 / 35 \\
66(57-73) \\
8 \cdot 9(5 \cdot 3-12 \cdot 9) \\
244(156-348) \\
58(35-96) \\
42(27-59)\end{array}$ \\
\hline
\end{tabular}

${ }^{\star} p<0.025 ;{ }^{\star \star} p<0.001$. Other differences not significant $(p>0.05)$.

1985, most being collected in the morning. Few specimens were obtained from patients with gynaecological malignancies because these patients were treated at separate hospitals in our health district. No patient was under our clinical care.

Microscopy of fresh (within two hours), unstained, unspun urine was performed by one of us (RG). When delay occurred the sample was discarded. When more than one leucocyte per high power field was seen the urine was considered unsuitable for biochemical analysis. No samples were obtained from patients with fevers, systemic disease known to be associated with proteinuria, or a history of renal disease. Urine from patients who had recently received nephrotoxic drugs or chemotherapy and those who had been catheterised or had ileal conduits was considered unsuitable. All patients had normal serum creatinine $(<125 \mu \mathrm{mol} / \mathrm{l})$ and plasma sodium concentrations.

The control group comprised the following people: patients with ischaemic heart disease (acute and chronic; $n=120$ ), patients admitted for routine surgery (general, vascular, orthopaedic, and other; $n=88$ ), patients with asthma and chronic obstructive airways disease $(n=56)$, patients with strokes and transient ischaemic attacks $(n=50)$, medical and nursing staff $(n=35)$, and miscellaneous patients whose symptoms had been investigated but in whom no organic disease had been found $(n=180)$.

A patient was considered to have a malignancy if there was unequivocal histological or radiological evidence of neoplasia at the time of urine collection. Patients with myeloma, urinary tract malignancies, or other urinary tract disease were excluded.

Tumours were grouped into 11 sites, and the numbers of patients with tumours at each were: gut, 166; lung, 106; breast, 83; lymphoreticular, 41; disseminated from an unknown primary tumour, 23; head and neck, 22; malignant melanoma, 20; basal cell carcinoma, 15; miscellaneous, 14; sarcoma, 8; and primary central nervous system, 6. The last four groups were too small (each less than $3 \%$ of the total) for individual analysis.

Length of survival of patients with malignancy (measured from the date of urine sampling) was initially obtained from hospital records, which recorded the date of death in 332 cases $(66 \%)$. In the other 172 only the last date when the patient was known to be alive was available; usually this was the date of an outpatient visit. Thus in order to increase the accuracy of survival data the deaths register of the Office of Population Censuses and Surveys (OPCS) was consulted. The names of all patients not known to have died were searched for in the records for the six months after their last outpatient visit. Twenty nine additional deaths were confirmed and were considered to have occurred half way through the quarter in which the patients' names were found (the OPCS records deaths by quarter year). Those who died in less than 14 days test and the $\chi^{2}$ statistic were applied. Actuarial survival analysis was performed, the generalised Wilcoxon statistic calculated, and survival analysis with covariates computed. ${ }^{18}$ Basal cell carcinomas are not fatal and patients with these tumours were excluded from the survival analysis.

\section{Results}

Proteinuria was more common $(\mathrm{p}<0.001)$ in patients with malignancies (290/504) than in control patients (119/529). Proteinuria greater than $0 \cdot 1 \mathrm{~g} / 1$ was also more common $(\mathrm{p}<0.001)$ in these patients $(174 / 504)$ than controls $(39 / 529)$. Median protein concentrations were $0 \cdot 14$ (interquartile range $0.07-0.29) \mathrm{g} / \mathrm{l}$ in patients with neoplasms and $0.07(0.05-0.12) \mathrm{g} / \mathrm{l}$ in controls $(p<0.001)$. There was no significant association between age and presence of proteinuria in controls or patients with tumours. Nevertheless, in patients with tumours the proportion who had proteinuria in excess of $0.1 \mathrm{~g} / \mathrm{l}$ increased with age $\left(\chi^{2}\right.$ for trend $\left.=5 \cdot 33 ; p<0.025\right)$.

Electrophoresis detected albumin in all samples. Variable amounts of $\alpha_{1}$ and $\beta_{2}$ microglobulins and immunoglobulins were found.

Table I gives details of patients in the two study groups. Sex distributions were the same but patients with malignancy were older (median age $64 v 54$ years; $p<0.01$ ). Urinary variables did not differ significantly between patients with neoplasia and controls except for median urinary sodium concentration, which was lower in patients with tumours $(65 \mathrm{mmol} / 1 v 83$ $\mathrm{mmol} / \mathrm{l} ; \mathrm{p}<0.001)$. Control patients who had proteinuria did not differ significantly from those without in respect of age, sex, and median urinary concentrations of creatinine, urea, and potassium, though their urinary sodium concentration was lower. Patients with tumours who had proteinuria had higher urinary concentrations of creatinine and urea and lower concentrations of sodium.

Table II shows that the prevalence of proteinuria with different tumours ranged from $45 \%$ ( $9 / 20$ cases; malignant melanoma) to $72 \%(120 / 166$; gut) and of proteinuria in excess of $0.1 \mathrm{~g} / \mathrm{l}$ from $25 \%$ (malignant melanoma (4/20) and breast $(21 / 83))$ to $52 \%$ (12/23; disseminated). Median urinary protein concentration in patients excreting more than $0 \cdot 1 \mathrm{~g} / 1$ ranged from $0 \cdot 18 \mathrm{~g} / 1$ (tumours of head and neck) to $0.30 \mathrm{~g} / \mathrm{l}$ (malignant melanoma).

Seventy six urine samples were obtained less than two weeks before death but, conversely, 74 patients were alive two years after sampling. Deaths within two weeks of sampling were similar in the three largest groups (gut $20 \%$ (33 patients), lung $25 \%$ (27), breast $25 \%$ (21)). A total of 361 of the 504 patients with malignancy $(72 \%)$ were known to have died (gut, 107 patients 
$(64 \%)$; lung, $89(84 \%)$; breast, $42(51 \%)$; others, $123(83 \%))$. The prognosis of patients with neoplasia complicated by proteinuria was compared with that of patients without proteinuria. The figure shows that the median survival of those with proteinuria was roughly half that of those without ( 4.5 $v 10$ months). This finding was unchanged when men and women were analysed separately. It was also the same when patients with urinary protein

TABLE II-Prevalence and concentration of proteinuria in patients with tumours at seven commonest sites

\begin{tabular}{|c|c|c|c|c|c|}
\hline Tumour site & $\begin{array}{c}\text { Median } \\
\text { age } \\
\text { (years) }\end{array}$ & $\begin{array}{c}\text { No of } \\
\text { patients }\end{array}$ & $\begin{array}{l}\text { No }(\%) \text { with } \\
\text { proteinuria }\end{array}$ & $\begin{array}{l}\text { No }(\%) \text { with } \\
\text { proteinuria } \\
\geqslant 0.1 \mathrm{~g} / \mathrm{l}\end{array}$ & $\begin{array}{l}\text { Median concentration } \\
\text { of proteinuria } \\
\geqslant 0 \cdot 1 \mathrm{~g} / 1 \\
\text { (interquartile range) }\end{array}$ \\
\hline Gut & 68 & 166 & $120(72)$ & $77(46)$ & $0.29(0.18-0.66)$ \\
\hline Lung & 64 & 106 & $53(50)$ & $30(28)$ & $0.22(0.15-0.60)$ \\
\hline Breast & 60 & 83 & $39(47)$ & $21(25)$ & $0.20(0 \cdot 15-0 \cdot 26)$ \\
\hline Lymphoreticular & 61 & 41 & $25(61)$ & $16(39)$ & $0.23(0.17-0.41)$ \\
\hline Disseminated & 72 & 23 & $16(70)$ & $12(52)$ & $0.26(0 \cdot 18-0 \cdot 44)$ \\
\hline Head and neck & 63 & 22 & $12(55)$ & $7(32)$ & $0.18(0.11-0.23)$ \\
\hline Malignant melanoma & 61 & 20 & $9(45)$ & $54(20)$ & $0.30(0.15-0.31)$ \\
\hline
\end{tabular}

concentrations of $<0.1 \mathrm{~g} / \mathrm{l}$ were grouped with those with no proteinuria and compared with those with concentrations of $>0 \cdot 1 \mathrm{~g} / \mathrm{l}$.

The prognostic value of proteinuria was determined for patients in the three largest tumour groups individually and for all the remaining patients as a single group. Survival curves for each group were similar to those in the figure. Table III gives the median durations of survival and interquartile ranges derived from them.

Patients were grouped as follows according to urinary protein concentration and median survival times calculated: nil ( 214 patients), $<0 \cdot 1 \mathrm{~g} / 1(116)$, $0 \cdot 1-0.25 \mathrm{~g} / 1(89),>0.25 \mathrm{~g} / 1$ (85). Median survival times were $10,6,4.5$, and 3.5 months respectively (generalised Wilcoxon statistic $=17 \cdot 2, \mathrm{df}=3$, $p<0.001)$. Table IV gives further information on survival of patients with time according to the amount of proteinuria. Survival analysis with covariates confirmed that proteinuria was significantly associated with a reduced survival time $(p<0.001)$ independently of tumour site.

\section{Discussion}

We found that proteinuria was common in patients with malignancy and that this was not due to the age of the population studied. Proteinuria in these patients was associated with a $50 \%$ reduction in

TABLE III-Median durations of survival stratified by sites of tumours and presence or absence and physiological degrees of proteinuria (actuarial survival analysis)

\begin{tabular}{|c|c|c|c|c|c|c|}
\hline \multirow{3}{*}{$\begin{array}{l}\text { Tumour } \\
\text { site }\end{array}$} & \multirow{3}{*}{$\begin{array}{l}\text { No of } \\
\text { patients }\end{array}$} & \multirow{3}{*}{$\begin{array}{l}\text { No of } \\
\text { confirmed } \\
\text { deaths }\end{array}$} & \multicolumn{4}{|c|}{ Median survival in months (interquartile range) } \\
\hline & & & \multicolumn{2}{|c|}{ Proteinuria } & \multicolumn{2}{|c|}{ Proteinuria } \\
\hline & & & Absent & Present & Absent or $<0 \cdot 1 \mathrm{~g} / \mathrm{l}$ & $>0.1 \mathrm{~g} / 1$ \\
\hline Gut & 166 & 107 & $7 \cdot 5(2 \cdot 5-38 \cdot 0)$ & $5 \cdot 0(2 \cdot 0-24 \cdot 0)$ & $7 \cdot 5(3 \cdot 0-38 \cdot 0)^{\star \star}$ & $4 \cdot 0(1 \cdot 0-18 \cdot 0)$ \\
\hline Lung & 106 & 89 & $5 \cdot 5(1 \cdot 5-15 \cdot 0)$ & $3 \cdot 0(0 \cdot 5-8 \cdot 0)$ & $4 \cdot 5(1 \cdot 0-13 \cdot 0)^{\star}$ & $1.5(0.5-6 \cdot 5)$ \\
\hline Breast & 83 & 42 & $14 \cdot 0+$ & $14 \cdot 0 \dagger$ & $14 \cdot 0 \dagger$ & $14 \cdot 0 \dagger$ \\
\hline Others & 149 & 123 & $14 \cdot 5(3 \cdot 0-43 \cdot 0)^{\star \star}$ & $5 \cdot 0(1 \cdot 0-15 \cdot 0)$ & $9 \cdot 0(2 \cdot 0-32 \cdot 0)^{\star}$ & $4 \cdot 5(1 \cdot 0-22 \cdot 0)$ \\
\hline
\end{tabular}

TABLE IV-Numbers (percentages) of patients surviving at six monthly intervals stratified by amount of proteinuria (actuarial survival analysis)

\begin{tabular}{lrrrrc}
\hline & \multicolumn{5}{c}{ Time in months } \\
\cline { 2 - 6 } Proteinuria ( $/ \mathbf{l})$ & \multicolumn{1}{c}{0} & \multicolumn{1}{c}{6} & \multicolumn{1}{c}{12} & 18 & 24 \\
\hline 0 & 214 & $124(58)$ & $102(48)$ & $83(39)$ & $76(36)$ \\
$<0-0 \cdot 1$ & 116 & $57(49)$ & $40(34)$ & $32(28)$ & $25(22)$ \\
$0 \cdot 1-0 \cdot 25$ & 89 & $37(42)$ & $27(30)$ & $22(25)$ & $20(22)$ \\
$>0 \cdot 25$ & 85 & $35(41)$ & $24(28)$ & $20(24)$ & $15(18)$ \\
\hline
\end{tabular}



Actuarial survival curves of patients with and without proteinuria. median survival. We cannot explain the observed differences in urinary concentrations of urea, creatinine, and sodium between patients with and without proteinuria.

Projected median survival (figure, table III) was reliable because of the large numbers of confirmed deaths. A total of 245 of these $(68 \%)$ were directly related to the malignancy. Causes of the remainder were unknown, but probably most were due to the neoplasms.

No effort was made to obtain urine samples from patients with specific tumours or at any particular stage. The population sampled included patients admitted for the first time for diagnosis and treatment as well as those with recurrent disease receiving further treatment or terminal care. The pattern of early deaths suggests that there was a similar proportion of advanced tumours among patients with and without proteinuria.

Proteinuria of up to $0.05 \mathrm{~g} / \mathrm{l}$ cannot reliably be distinguished from zero because of the coefficient of variation of the assay. Furthermore, minor degrees of proteinuria (up to $0 \cdot 1 \mathrm{~g} / 24 \mathrm{~h}$ ) ${ }^{19}$ are physiological, so that if urine output is about one litre a day ${ }^{20}$ concentrations of up to $0.1 \mathrm{~g} / \mathrm{l}$ may be normal. Our data were therefore reanalysed comparing patients without proteinuria and with proteinuria of up to $0.1 \mathrm{~g} / \mathrm{l}$ with those with greater concentrations (tables II and III). We also applied the formula of Ginsberg et al to estimate 24 hour urinary protein excretion from single samples. ${ }^{21}$ Further analysis by using the calculated 24 hour protein excretion and considering $0 \cdot 1 \mathrm{~g} / 24 \mathrm{~h}$ or less as physiological was also performed. Our conclusions were unchanged by either of these analyses.

Earlier laboratory work has shown that immunological change is common in kidneys of patients who have died of malignancy. ${ }^{9 \cdot 11}$ Only 10 of the 361 patients known to have died in our series came to necropsy. We were therefore unable to undertake immunoperoxidase studies on glomeruli ${ }^{22}$ and could not correlate proteinuria with structural changes. There is a need for a similar study to be repeated in a hospital in which postmortem examination 
is routine. Our observations (table III) suggest that patients with tumours of the gut or lung should be the most informative to study. Timed sequential urine collections should be obtained to quantify this proteinuria, measure its constituents, confirm its prevalence, verify the prognostic importance, and determine the incidence. We further recommend that an assay sensitive at low concentrations should be used because the sensitivity of the turbinometric assay is poor. ${ }^{23}$ Nevertheless, this assay is used routinely and thus our findings are clinically applicable.

Possibly a subclinical nephritis or other form of renal damage related to malignancy is reflected by these low concentrations of proteinuria. When our data are replicated oncologists might quantify their patients' proteinuria, which may prove to be an additional prognostic feature.

We thank the nurses who collected samples, our consultant colleagues for their cooperation, and the staff of St Mary's Hospital computer unit.

\section{References}

1 Kaplan BS, Klassen J, Gault MH. Glomerular injury in patients with neoplasia. Annu Rev Med $1976 ; 27: 117-25$

2 Eagen JW, Lewis EJ. Glomerulopathies of neoplasia. Kidney Int 1977;11:297-306.

3 Couser GW, Wagonfield JB, Spargo BH, Lewis EJ. Glomerular deposition of tumor antigen in membranous nephropathy associated with colonic carcinoma. Am F Med 1974;57:962-70.

4 Anonymous. Non-renal neoplasms and the kidney [Editorial]. Lancet 1975;i:24-5.

5 Ghosh BL, Muehrcke RC. The nephrotic syndrome: a prodrome to lymphoma. Ann Intern Med 1970;72:379-82.
6 Moorthy AV, Zimmerman SW, Burkholder PN. Nephrotic syndrome in Hodgkin's disease. Am f Med 1976;61:471-7.

7 Costanza ME, Pinn V, Schwartz RS, Nathanson L. Carcinoembryonic antigen-antibody complexes in a patient with colonic carcinoma and nephrotic syndrome. $N$ Engl $\mathcal{F}$ Med 1973;289:520-2.

8 Olson JL, Philips TM, Lewis MG, Solez K. Malignant melanoma with renal dense deposits containing tumour antigens. Clin Nephrol 1979;12:74-82.

Sutherland JC, Markham RV, Mardiney MR. Subclinical immune complexes in the glomeruli of kidneys postmortem. Am f Med 1974;57:536-41.

10 Pascal RR, Iannoccone PM, Rollwagen FM, Harding TA, Bennett SJ. Electron microscopy and immunofluorescence of glomerular immune complex deposits in cancer patients. Cancer $R e$ 1976;36:43-7.

11 Beaufils H, Jouanneau C, Chomette G. Kidney and cancer: results of immunofluorescence microscopy. Nephron 1985;40:303-8.

12 Rudman D, Rio A, Akgum S, Frumin E. Novel proteins and peptides in the urine of patients with advanced neoplastic disease. Am $\mathcal{F}$ Med 1969;46:174-87.

13 Hemmingsen L, Skaarup P. Urinary excretion of ten plasma proteins in patients with extrarenal epithelial carcinoma. Acta Chir Scand 1977;143:177-83

14 Kannel WB, Stampfer MJ, Castelli WP, Verter J. The prognostic significance of proteinuria: the Framingham study. Am Heart $\mathcal{f}$ 1984;108:1347-52

15 Viberti GC, Hill RD, Jarrett RJ, Argyropaulos A, Mahmud Y, Keen H. Microalbuminuria as a predictor of clinical nephropathy in insulin-dependent diabetes mellitus. Lancet 1982;i:1430-2. 16 Gosling P, Sutcliffe AJ. Proteinuria following trauma. Ann Clin Biochem 1986;23:681-5.

17 Armitage P, Berry G. Statistical methods in medical research. Oxford: Blackwell Scientific, 1987.

18 Dixon WJ, ed. Biomedical data package statistical software. Los Angeles, London: University of California Press, 1983

19 Pruzanski W, Ogryzlo MA. Abnormal proteinuria in malignant diseases. Adv Clin Chem 1970;13:338.

20 Lentner C, ed. Units of measurement, body fluids, composition of the body, nutrition. In: Geigy scientific tables. Vol 1. Basle: Ciba-Greigy Ltd, 1981:55.

21 Ginsberg JM, Chang BS, Matarese RA, Garella S. Use of single voided urine samples to estimate quantitative proteinuria. $N$ Engl f Med 1983;309:1543-6.

22 Sinclair RA, Burns J, Dunnill MS. Immunoperoxidase staining of formalin fixed, paraffinembedded, human renal biopsies with a comparison of the peroxidase-antiperoxidase (PAP) and indirect methods. F Clin Pathol 1981;34:859-65.

23 Balant LP, Fabre J. Clinical significance of proteinuria. Compr Ther 1978;4:54-62.

(Accepted 4 March 1988)

\section{SHORT REPORTS}

\section{Studies on platelets before and after stroke in a patient with essential thrombocythaemia}

Only limited data on the aggregation of platelets before stroke are available; we investigated the behaviour of platelets three days before and four days after acute stroke in a patient with thrombocythaemia.

\section{Case report}

The patient was a 72 year old man who had had a stroke nine months earlier and been prescribed aspirin $300 \mathrm{mg}$ once weekly. Two months later he had developed a mild left hemiparesis and had signs reflecting disorganisation of the aortic valve. A computed tomogram of the head showed diffuse cerebral atrophy but no focal lesion. The platelet count was raised $\left(766 \times 10^{9} / 1\right)$, and results of subsequent laboratory investigations were consistent with essential thrombocythaemia. We concluded that he probably had emboli in the right cerebral hemisphere and prescribed aspirin $1200 \mathrm{mg}$ and dipyridamole $400 \mathrm{mg}$ daily.

He remained well for seven months, when he presented with a focal fit affecting the left arm. Cardiac signs were unchanged, there were no signs of subacute bacterial endocarditis, and cultures of blood yielded negative results. The platelet count was $906 \times 10^{9} / 1$. Aspirin and dipyridamole were withdrawn and phenytoin sodium $200 \mathrm{mg}$ nightly was started. The focal epileptic fit was thought to have been related to cortical scarring after his previous strokes.

Thirteen days later he returned as an outpatient, feeling well and having had no further neurological symptoms. His platelet count was $852 \times 10^{9} / 1$, and detailed platelet studies were performed. Three days later he was readmitted to hospital, having collapsed and developed a right hemiplegia. Initially he seemed to recover, and four days after admission blood was taken for platelet studies; the platelet count had fallen to $557 \times 10^{\%} / \mathrm{l}$. His condition deteriorated rapidly shortly afterwards, and he died a day later. Consent for a necropsy was refused.

Platelet studies-Aggregation of platelets was measured in stirred citrated whole blood and heparinised whole blood with a platelet counting technique Results were compared with those for 20 apparently healthy men (mean age 71 , range 61-83). The figure shows that the patient's platelets were hyperaggregable before the stroke and hypoaggregable afterwards. Resistance of aggregation to epoprostenol was assessed in plasma rich in platelets prepared from heparinised blood with $1 \mathrm{mmol}$ sodium arachidonate/l as the aggregating agent. ${ }^{2}$ The results were compared with those for 14 apparently healthy men (mean age 70, range 61-83). A concentration of $10 \mathrm{nmol} / \mathrm{l}$ epoprostenol was sufficient to preven completely the aggregation of platelets (and the release reaction that accompanie it) in plasma from the controls; in contrast, $25 \mathrm{nmol} / \mathrm{l}$, the highest concentration of epoprostenol used, did not affect aggregation of platelets in plasma taken from the patient either before or after his stroke.
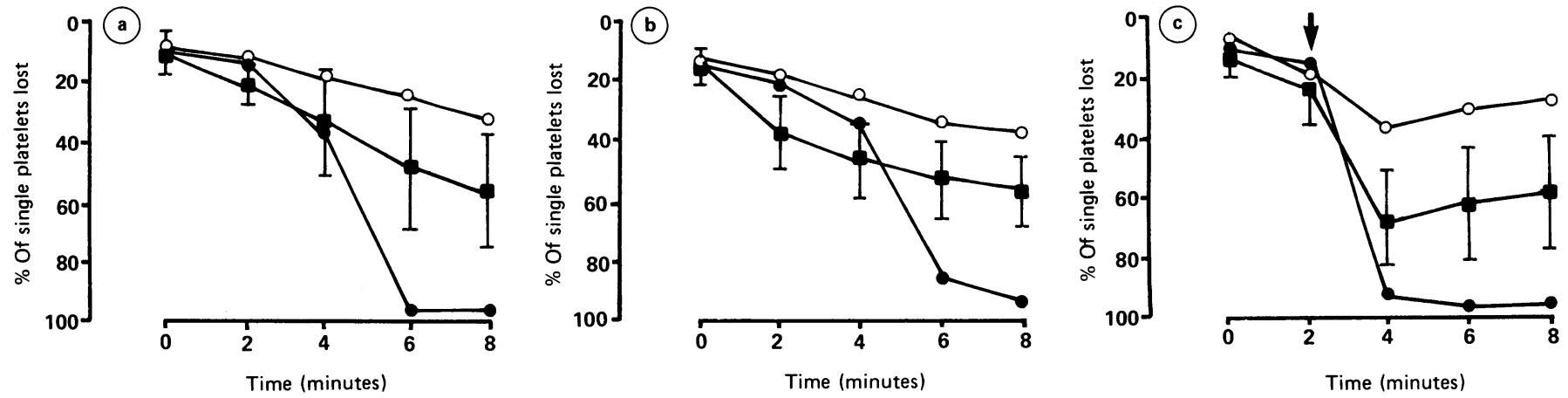

Platelet aggregation (percentage of single platelets lost) occurring in (a) stirred citrated blood; $(b)$ stirred heparinised blood; and (c) citrated bloud to which adenosine diphosphate $(0.5 \mu \mathrm{mol} / \mathrm{l})$ was added (arrowed). $=$ Patient before stroke; $\bigcirc=$ patient after stroke; $\square$ and vertical bars=mean $(\mathrm{SD})$ value in 20 controls. 